\title{
HUBUNGAN LAMA PEMBERIAN AIR SUSU IBU DENGAN PRESTASI AKADEMIK SISWA KELAS 1 SEKOLAH DASAR AR RISALAH KARTASURA SUKOHARJO
}

\author{
Burhannudin Ichsan $^{1}$, Bayu Hendro Wibowo ${ }^{2}$, M. Nur Sidiq ${ }^{2}$ \\ 1. Lecturer of School of Medicine, Muhammadiyah University of Surakarta \\ 2. Student of School of Medicine, Muhammadiyah University of Surakarta \\ Correspondence to: Burhannudin Ichsan \\ Email: Burhannudin.Ichsan@ums.ac.id
}

\begin{abstract}
ABSTRAK
Air susu ibu (ASI) adalah makanan ideal bayi baru lahir. Allah menyediakan nutrisi terbaik untuk bayibayi dalam bentuk air susu ibu. Bukti-bukti telah mendokumentasikan keuntungan-keuntungan ASI untuk ibu dan bayi. Banyaknya manfaat yang nyata termasuk perkembangan kognitif yang bagus untuk anak belum dapat memotivasi orang tua utamanya ibu untuk menyusui secara optimal bayi-bayi mereka.Tujuan dari penelitian ini untuk menganalisis hubungan antara lama memberi ASI dengan capaian akademik anak pada tahun pertama SDIT Ar Risalah Kartasura Sukoharjo. Tempat penelitian adalah SDIT Ar Risalah Kartasura, Sukoharjo. Penelitian dilakukan pada bulan oktober 2014. Penelitian ini menggunakan rancangan analitik obseravsional dengan pendekatan cross sectional. Populasi penelitian adalah anak usia sekolah dengan ukuran sampel 80 . Hasil dari pengukuran dalam bentuk jawaban ibu yang menyatakan berapa bulan, minggu dan hari dalam menyusui anak dan kemudian dikonversi ke dalam ukuran hari. Variabel terikat adalah capaian akademik dalam skala pengukuran numerik. Capaian akademik diukur dengan melihat nilai rapor anak. Hasil dari dua variabel dianalisis menggunakan korelasi spearman dengan SPSS versi 16.0. Hasil menunjukkan korelasi sangat lemah antara lama ASI dengan capaian akademik siswa kelas I SDIT Ar Risalah, Kartasura, Sukoharjo yang secara statistik tidak bermakna. Terdapat korelasi yang sangat lemah antara lama pemberian ASI dengan capaian akademik siswa kelas satu SDIT Ar Risalah Kartasura, Sukoharjo yang secara statistik tidak bermakna.
\end{abstract}

Kata Kunci: ASI, lama, capaian akademik

\section{ABSTRACT}

Breastfeeding is an ideal food for newborns. Allah provides the best nutrition for infants in the form of breastfeeding. Substantial evidences documented the advantages of breastfeeding for mother and infant. The number of real benefits of breastfeeding including cognitive development that is good for the child is not yet able to motivate parents primarily mothers to breastfeed optimally to his children. The aim of this study is to analyze the relationship between the length of breastfeeding to the child's academic achievement of the first year of SDIT Ar Risalah Kartasura Sukoharjo. This study was done at Ar Risalah elementary School of Kartasura, Sukoharjo. The research was conducted in October2014.This study used observation alanalytic design with cross sectional approach. The study population were children of school age with a large sample of 80 . The results of measurements in the form of answers to the mother stating how many months, weeks and days breastfeed the child and than is converted to days. The dependent variable is the academic achievement with numerical measurement scale. The academic achievement was measured by looking at the child's grades. Results of both variables then be correlated. Data analysis used spearman correlation using SPSSversion 16.0. The result shows a very weak correlation between the length of breastfeeding to student achievement grade 1 Ar Risalah elementary School of Kartasura, Sukoharjo which was not statistically significant. There is a very weak correlation between the length of breastfeeding to student achievement of first year student at Ar Risalah elementary School of Kartasura, Sukoharjo which was not statistically significant.

Keywords: breastfeeding, duration, academic achievement 


\section{PENDAHULUAN}

Air susu ibu(ASI) merupakan makanan yang ideal untuk bayi baru lahir. Allah menyediakan nutrisi yang paling baik untuk bayi yang berupa ASI. Bukti substansial mendokumentasikan keunggulan ASI untuk ibu dan untuk bayi (DiFrisco etal. 2011). Bayi sebaiknya diberi hanya ASI saja sampai usia enam bulan kehidupan pertamanya.

Di samping zat-zat yang terkandung di dalamnya, pemberian ASI juga memiliki beberapa manfaat yaitu: a) steril, aman dari pencemaran kuman, b) selalu tersedia dengan suhu optimal, c) produksi disesuaikan dengan kebutuhan bayi, d) terdapat antibodi yang bisa menghambat pertumbuhan atau membunuh kuman atau virus, dan e) bahaya alergi tidak ada (Suraatmaja 2013).

ASI mengurangi risiko penyebabpenyebab umum dari kesakitan bayi, termasuk, tetapi tidak terbatas pada meningitis bakterial, necrotizingenterocolitis, infeksi saluran pernapasan, otitis media dan diare. ASI memperbaiki hasil perkembangan saraf untuk bayi preterm dan mungkin juga berpengaruh manfaat kesehatan jangka lama seperti jumlah rendah yang bermakna dari juvenilediabetes, kolitis ulseratif, limfoma, obesitas dan asma (DiFrisco etall. 2011). Menurut Iacovou \& Sanz (2010), terdapat hubungan yang mapan antara ASI dengan hasilhasil kesehatan yang positif pada anak, seperti insiden yang rendah dari asma, infeksi telinga tengah dan infeksi saluran kencing.

Makanan bayi dan anak kecil merupakan hal yang kritis untuk kesehatan anak dan kelangsungan hidupnya. Berdasarkan hasil penelitian yang sahih, WHO dan UNICEF merekomendasikan ibu-ibu untuk menempatkan bayi ke payudara dalam waktu satu jam setelah melahirkan, memberikan ASI eksklusif selama enam bulan pertama dan melanjutkan memberi ASI selama dua tahun dan lebih bersama-sama dengan nutrisi lain yang adekuat (Cai, Wardlaw, \& Brown 2012).

Untuk enam bulan pertama kehidupannya, ASI saja adalah merupakan makanan ideal, yang menyediakan semua nutrisi, termasuk vitamin dan mineral, kebutuhan-kebutuhan bayi, artinya tidak diperlukan pemberian cairan atau makanan lain. Sebagai tambahan, ASI membawa antibodi dari ibu yang mambantu melawan penyakit, melindungi bayi dari diare dan infeksi pernapasan akut. ASI juga merangsang sistem daya tahan bayi, respon terhadap vaksinasi dan, menurut beberapa penelitian memberikan manfaat kognitif juga. Pemberian ASI di atas enam bulan dibarengi dengan makanan padat, semi padat, maupun lunak yang cukup kuantitas, aman, kandungan gizinya adekuat, juga membantu menjamin status gizi yang baik dan melindungi dari penyakit-penyakit. Diperkirakan bahwa ASI yang optimal untuk anakanak di bawah dua tahun berpotensi mencegah 1,4 juta kematian anak di bawah lima tahun di negara berkembang setiap tahun (Cai, Wardlaw, \& Brown 2012).

ASI mungkin memiliki efek manfaat pada perkembangan anak, remaja, dan bahkan dewasa, meskipun ini belum merupakan temuan yang konsisten. Lebih jauh, beberapa penelitian menunjukkan bahwa lamanya pemberian ASI eksklusif penting untuk hasil perkembangan yang baik pada masa anak-anak, terutama bagi mereka yang lahir kecil untuk usia kehamilan. Sementara kebanyakan penelitian telah fokus pada perkembangan kognitif, kurang diketahui akibat ASI dan lamanya pemberian ASI eksklusif pada perkembangan non-kognitif dan status perilaku di masa kanak-kanak (Jonsdottir etall. 2013). Menurut Anderson etal. (1999) dalam sebuah penelitian meta-analysis menyebutkan bahwa setelah penyesuaian dengan cofactors kunci yang sesuai, ASI berhubungan denagn skor yang lebih tinggi secara bermakna dengan perkembangan kognitif dibandingkan dengan yang diberi formula (formula feeding).

Banyaknya manfaat nyata ASI termasuk di dalamnya perkembangan kognitif yang baik bagi anak ternyata belum dapat memotivasi orang tua utamanya para ibu untuk dapat memberikan ASI secara maksimal pada anak-anaknya. Data menunjukkan, prevalensi ASI eksklusif secara global di dunia yaitu 39\%, prevalensi di negaranegara berpenghasilan rendah diperkirakan 36\% (Nkala \& Msuya 2011). Cakupan ASI eksklusif nasional tahun 2009 sebesar 61,3\%, sedangkan cakupan untuk Jawa Tengah tahun 2009 sebesar 52,2\%(KementerianKesehatanRepublikIndonesia 2011). Cakupan global, nasional maupun provinsi Jawa Tengah masih di bawah target global maupun nasioanal. Menurut Nkala \&Msuya (2011), target prevalensi ASI eksklusif oleh WHO yaitu 91\%, sedangkan target nasional ASI eksklusif menurut InitiativesforGovernanceInovation (2012) yaitu $80 \%$.

Berkaitan dengan hubungan pemberian ASI 
yang maksimal dengan perkembangan kognitif anak, maka perlu diperhatikan mengingat tuntutan zaman yang semakin maju yang menghendaki tingkat kecerdasan dan tingkat pencapaianpencapaian akademik yang tinggi pula. Ditambah dengan persaingan masyarakat global yang semakin kuat, seperti mulai berlakunya masyarakat ekonomi Asean 2015, maka perlu didukung sumber daya manusia yang semakin berkualitas. Salah satu usaha yang dapat dilakukan yaitu meningkatkan nutrisi anak sejak usia dini yaitu dengan pemberian ASI eksklusif dan atau pemberian ASI sampai jangka yang lebih lama yaitu sampai minimal dua tahun tentu dengan ditambah makanan tambahan yang adekuat. Dari latar belakang yang demikian, peneliti ingin mengkonfirmasi hubungan antara lamanya pemberian ASI dengan pencapaian akademik anak, sehingga hasil yang didapatkan bisa menjadi dasar untuk lebih meningkatkan motivasi ibu-ibu dalam memberikan ASI eksklusif maupun menambah jangka lamanya pemberian ASI kepada anak-anaknya.

Penelitian ini bertujuanuntuk menganalisis hubungan lamanya pemberian ASI dengan pencapaian akademik anak kelas 1 SD Ar Risalah Kartasura Sukoharjo

\section{METODE}

Tempat penelitian dilakukan di SDIT Arrisalah Kartasura, Sukoharjo. Waktu penelitian dilaksanakan pada bulan Oktober 2014. Penelitian ini menggunakan rancangan penelitian observasional analitik dengan pendekatan crosssectional. Populasi penelitian ini yaitu anak-anak usia sekolah. Sampel diambil dengan purposivesampling. Besar sampel yaitu 80 . Variabel bebas yaitu lamanya pemberian ASI dengan skala pengukuran numerik, dengan cara pengukuran ibu anak diberi kuesioner yang salah satu isinya adalah menanyakan lamanya pemberia ASI kepada anaknya. Hasil pengukuran berupa jawaban ibu yang menyatakan berapa bulan, minggu dan hari memberikan ASI kepada anaknya. Selanjutnya lama ASI dikonversi menjadi hhari. Variabel terikat yaitu prestasi akademik denga skala pengukuran numerik. Cara pengukuran dnegan melihat nilai rapor anak. Hasil kedua variabel kemudian dikorelasikan. Analisis data menggunakan korelasi productmoment dengan menggunakan program SPSS versi 16.0.

\section{HASIL DAN PEMBAHASAN}

Setelah dilakukan penelitian tentang hubungan lama pemberian air susu ibu dengan prestasi akademik siswa kelas 1 SDIT Ar Risalah Kartasura, Sukoharjo, didapatkan hasil sebagai berikut :

Tabel 1. Distribusi frekuensi lama pemberian ASI dan prestasi

\begin{tabular}{lll}
\hline \multicolumn{1}{c}{ Hasil } & \multicolumn{1}{c}{ Lama pemberian ASI } & \multicolumn{1}{c}{ Prestasi } \\
\hline Mean & 554,69 & 92,92 \\
Median & 714,00 & 93,20 \\
Standar deviasi & 244,60 & 2,57 \\
Maksimum & 912,50 & 96,90 \\
Minimum & 0 & 84,60 \\
\hline
\end{tabular}

Tabel 2. Korelasi antara lama pemberian ASI dan prestasi siswa SDIR Ar Risalah Kartasura, Sukoharjo

\begin{tabular}{ll}
\hline Koefisien korelasi (r) & $\mathrm{p}$ \\
\hline 0,048 & 0,670 \\
\hline
\end{tabular}

Hasil penelitian menunjukkan terdapat korelasi yang sangat lemah antara lama pemberian ASI dengan prestasi akademik siswa SDIT Ar Risalah Kartasura, Sukoharjo yang secara statistik tidak bermakna. Pembahasan tentang hasil penelitian disampaikan berikut.

Hasil penelitian ini tidak sesuai dengan teori yang menyebutkan bahwa ASI mungkin memiliki efek manfaat pada perkembangan anak, remaja, dan bahkan dewasa. Lebih jauh, beberapa penelitian menunjukkan bahwa lamanya pemberian ASI eksklusif penting untuk hasil perkembangan yang baik pada masa anak-anak, terutama bagi mereka yang lahir kecil untuk usia kehamilan (Jonsdottir etall. 2013).

ASI mengandung nutrisi untuk perkembangan otak dan pertumbuhan bayi (Mexitalia 2011). Kadar methionin dalam ASI lebih rendah dari air susu sapi (ASS), sedangkan sistin lebih tinggi. Hal tersebut sangat menguntungkan sebab enzim sistationase yaitu enzim yang akan mengubah methionin menjadi sistin pada bayi sangat rendah atau tidak ada. Sistin tersebut 
merupakan asam amino yang sangat penting untuk pertumbuhan otak bayi (Suraatmaja 2013). Menurut beberapa penelitian ASI memberikan manfaat kognitif juga (Cai, Wardlaw, \& Brown 2012). Hasil ini juga berbeda dengan beberapa penelitian sebagai berikut.

Oddy etal. (2010) meneliti kaitan lama nenyusui dengan prestasi akademik pada 10 tahun. Dengan metode kohor, mereka mendapatkan bahwa menyusui (yang utama) selama enam bulan atau lebih berhubungan secara positif dengan prestasi akademik pada anak usia sepuluh tahun, tetapi keefektifan dari ASI tersebut berbeda menurut jenis kelamin, yaitu manfaatnya hanya tampak pada laki-laki.

Boccanfuso etal. (2010) menyatakan bahwa penelitian menemukan bahwa anak-anak yang diberi ASI selama beberapa bulan lebih mungkin memperlihatkan skor IQ dan kemampuan kognitif yang lebih tinggi sepanjang proses sekolah. ASI lebih dari tujuh bulan juga ditemukan dapat melindungi kelambatan pada perkembangan bahasa dan keterampilan motorik dan memprediksi IQ yang lebih tinggi secara bermakna pada masa dewasa.

Korelasi yang sangat lemah dan tidak bermakna secara statistik ini mungkin disebabkan beberapa hal yang mungkin juga merupakan kelemahan-kelemahan dari penelitian ini. Beberapa kelamahan disebutkan berikut ini.

Kelemahan pertama yaitu tidak ditelitinya variabel motivasi pada anak. Kelemahan kedua, dari jumlah sampel yang diperlukan yaitu 92, hanya 80 sampel yang dapat dianalisis. Kelemahan ketiga yaitu, dalam mengkonversi satuan bulan dan minggu ke satuan hari ada hal-hal tidak konsisten yang tidak dapat dihindari, sebagai contoh kadang satu bulan dianggap 30 hari kadang enam bulan adalah setengah dari 365 hari, dan sebagainya. Kelemahan keempat, lama ASI hanya menunjukkan satu aspek saja, tetapi tidak dapat menunjukkan kualitas pemberian perharinya dan juga tidak dapat menujukkan mana yang eksklusif dan mana yang tidak.

Di samping kelemahan-kelemahan yang ada, sebenarnya penelitian ini juga memiliki kekuatan. Kekuatan dari penelitian ini yang pertama, sebenarnya penelitian ini melibatkan hampir semua siswa kelas satu SDIT Ar Risalah Kartasura, Sukoharjo, artinya tidak menggunakan sampel tetapi populasi. Kelebihan berikutnya yaitu sudah terdapat usaha untuk mengeksklusi varaiabel-variabel yang diduga dapat menjadi pengganggu seperti gangguan kepribadian dan kondisi kesehatan siswa.

\section{SIMPULAN}

Terdapat korelasi yang sangat lemah antara lama pemberian ASI dengan prestasi akademik siswa kelas satu SDIT Ar Risalah Kartasura, Sukoharjo yang secara statistik tidak bermakna.

\section{SARAN}

Diperlukan penelitian yang lebih rinci dengan lebih memperhatikan variabel-variabel lain yang kemungkinan mengganggu hasil penelitian. Diperlukan desain yang lebih baik seperti desain casecontrol atau bahkan kohor untuk melihat hubungan yang lebih baik.

\section{DAFTAR PUSTAKA}

Anderson, J.W. Johnstone, B.M. \& Remley, D.T. 1999. Breast-feeding and Cognitive Development: a Meta-Analysis. Am J Clin Nutr; 70: 52535.

Boccanfuso, C. Moore, K.A. \& Whitney, C. 2010. Ten Ways to Promote Education Achievement and Attainment Beyond the Classroom. Brief Research to Results Child Treds. Diunduh dari: http://www.mentoring.org/downloads/ mentoring_1263.pdf. Diakses pada tanggal 4 September 2014.

Cai, X. Wardlaw, T. \& Brown, D.W. 2012. Global Trends in Exclusive Breastfeeding. InternationalBreastfeedingJournal, 7:12.

DiFrisco, E. Goodman, K.E. Budin, W.C. Lilienthal, M.W. Kleinman, A. \& Holmes, B. 2011. Factors Associated With Exclusive Breastfeeding 2 to 4 Weeks Following Discharge from a Large, Urban, Academic, Medical, Center Striving for Baby-Friendly Designation. The Journal of Perinatal Education, 20(1):28-35

Iacovou, M. \& Sanz, A.S. 2010. The Effect of Breastfeeding on Children's Cognitive Development. UK: E.S.R.C.Economic \& Social Research Council. Diunduh dari: https://www.iser.essex.ac.uk/files/iser working papers/2010-40.pdf. diakses: $\overline{3}$ Sepetember 2014. 
Initiatives for Governance Innovation. 2012. Database Good Practice, Kelompok Pendukung Ibu (KP-Ibu) Kota Surakarta. Diunduh dari gi. Fisipol. ugm. ac.id/index2.php? option=com_sobi2...dd...? Diakses tanggal 17 Juli 2013.

Jonsdottir, O.H. Thorsdottir, I. Gunnlaugsson, G. Fewtrell, M.S. Hibberd, P.L. \& Kleinman, R.E. 2013. Nutrients, 5, 4414-4428.

Kementerian Kesehatan Republik Indonesia. 2011. Profil Kesehatan Indonesia 2010. Jakarta: Kementerian Kesehatan Republik Indonesia.

Mexitalia, M. 2011. Air Susu Ibu dan Menyusui dalam Sjarif, DR. Lestari, ED. Mexitalia, M. \& Nasar, SS. 2011. Buku Ajar Nutrisi Pediatrik dan Penyakit Metabolik.Jakarta: Badan Penerbit IDAI.
Nkala, T.E. \& Msuya, S.E. 2011. Prevalence and Predictors of Exclusive Breastfeeding among Women in Kigoma Region, Western Tanzania: a Community Based Cross Sectional Study. Breastfeeding Journal, 6 (17): 1-7

Oddy, W.H. Li, J. Whitehouse, A.J.O. Zubrick, S.R. \& Malacova, E. 2010. Breastfeeding Duration and Academic Achievement at 10 Years. Pediatrics, 127(1): e137-45

Suraatmaja. 2013. Aspek Gizi Air Susu Ibu dalam Soetjiningsih. 2013. Seri Gizi Klinik, ASI, Petunjuk Untuk Tenaga Kesehatan. Jakarta: EGC. 